\title{
Extent at Which Vocational Guidance Influence Career Decision of Vocational and Technical Students
}

\author{
Onojah Amos Ochayi ${ }^{*}$, Obielodan Omotayo Olabo², Onojah Adenike Aderogba ${ }^{3}$, \\ Koledafe Olawale Sunday ${ }^{4}$, Ishola Faruq Adebayor ${ }^{5}$, Aderele Shadrack 0motayo ${ }^{6}$ if \\ 1,2,3,4,5 University of Ilorin, Ilorin, Nigeria \\ *Corresponding author: ochayi89@gmail.com
}

\begin{abstract}
Abstrak
Bimbingan pribadi berpusat pada masalah kepribadian, perkembangan fisik dan emosional, hubungan interpersonal dan hal-hal serupa. Tapi bimbingan kejuruan yang diberikan kepada siswa mungkin atau mungkin tidak mempengaruhi karir mereka setelah lulus. Penelitian ini dengan demikian menguji sejauh mana bimbingan kejuruan mempengaruhi keputusan karir siswa kejuruan dan teknik. Penelitian ini merupakan penelitian deskriptif dengan tipe survey. Sampel 220 mahasiswa teknik semua mahasiswa pendidikan teknik di metropolis Ilorin. Frekuensi hitung dan mean digunakan untuk menjawab pertanyaan penelitian dan hipotesis diuji dengan uji-t pada taraf signifikansi 0,05. Temuan menetapkan bahwa bimbingan kejuruan telah mampu mempengaruhi pengambilan keputusan karir siswa pendidikan kejuruan dan teknik untuk tingkat yang tinggi. Juga, tidak ada perbedaan yang signifikan dalam dampak bimbingan kejuruan terhadap pilihan karir siswa sekolah menengah kejuruan dan pendidikan teknik. Oleh karena itu, direkomendasikan bahwa siswa Pendidikan Kejuruan dan Teknologi harus mengetahui pentingnya layanan bimbingan dan apa itu konseling agar mereka dapat membuat keputusan karir yang baik.
\end{abstract}

Kata kunci: Tingkat, Bimbingan Kejuruan, Pengaruh, Keputusan Karir, Mahasiswa Kejuruan Dan Teknik, Tingkat Kelas

\section{Abstract}

Personal guidance centers on problems of personality, physical and emotional development, interpersonal relations and similar matters. But vocational guidance given to students may or may not influence their career after graduation. This study thus examined extent at which vocational guidance influence career decision of vocational and technical students. This is a descriptive research design of the survey type. 220 technical students were sampled all technical education students in Ilorin metropolis. Frequency count and mean were used answer the research questions and Hypothesis was tested with t-test at 0.05 level of significance. The findings established that vocational guidance has been able to influence career decision making of vocational and technical education students to a high extent. Also, there was no significant difference in the impact of vocational guidance on career choice of junior and senior vocational and technical education students. It was therefore recommended that Vocational and Technology Education students should be exposed to the importance of guidance services and what counseling is all about in order for them to make good career decisions.

Keywords: Extent, Vocational Guidance, Influence, Career Decision, Vocational And Technical Students, Class Level

$\begin{array}{ll}\text { History: } & \text { Publisher: Undiksha Press } \\ \text { Received : August 12, } 2021 & \text { Licensed: This work is licensed under } \\ \text { Revised : August 13, 2021 } & \text { a Creative Commons Attribution 3.0 License } \\ \text { Accepted : September 04, 2021 } & \text { Pablished : October 25, 2021 }\end{array}$

\section{INTRODUCTION}

Vocational guidance is an important issue in human life as it affects person from childhood to maturity (Ezeji, 2014; Jiang, 2018; Turganbayev et al., 2021). It is the process of helping client to choose an occupation, prepare for it, enter it and develop in it. Such guidance should be rendered to the student, taking cognizance of his or her personality traits, interests, ability, values and so forth. This is because it will influence his life is/her style such as the type of food he/she eat, the type of cloth he/she wear, the type of house he/she live, his/her choice of friends and car he/she drives etc. Guidance may be conveniently classified into three major categories personal guidance, educational guidance, and vocational guidance. Personal guidance centers on problems of personality, physical and emotional development, interpersonal relations and similar matters (Gargalianos et al., 2021; Turganbayev et al., 2021). 
Educational guidance on the other hand is concerned chiefly with educational problems, choices, and adjustments (Jiang, 2018; Young, 2017). Some writers further categorize guidance into health guidance, social guidance, spiritual guidance and financial guidance. Regardless of the scheme of classification, the various types of guidance are inseparably related. Their difference is chiefly a matter of emphasis of the various age levels and stages of development in the life of the individual. Vocational guidance is a process of assisting an individual towards making a wise choice of occupation/career, which will be beneficial to him and to society (Ayçiçek, 2020; Bedi et al., 2021). It is the assistance given in choosing, preparing for, entering upon, and making progress in an occupation. Vocational guidance is a continuous means of assisting an individual to understand him/herself better as a basis for occupational decision. The process involves a continuous and careful assessment of an individual's interest, aptitude, and potentials over periods, using various sources of information from home and schools as a reliable basis for guiding the individual towards a satisfactory occupation. Vocational guidance can also be defined as that phase of the educational process in which conscious, organize planning for the future is a primary, rather than a secondary focus (El Haji et al., 2018; Haug et al., 2019).

Vocational education usually provided at upper secondary level, includes general education, practical training for development of skills required by the chosen occupations and related theory (Sahin, 2010; Verawadina et al., 2020). The proportions of these components may vary considerably but the emphasis is usually on practical training (Umeano, 2012; Wordu et al., 2013). This definition tends to pose problems of classification based on the level of entry of work, proportion of theoretical and scientific studies and emphasis on practical training. To avoid such debate in classification and to improve the development in this type of education, the current trends in education and planning and practices is to use a single term "technology education to embrace all such education programs. Technology deals with the application of knowledge in the solution of practical problems of everyday living. Technology education, essentially aims at developing techniques, devices, procedures and the process for doing things (Ferguson \& Hull, 2019). Obviously, theoretical and scientific studies and related skill training are required. These components will vary according to the level of education and the nature of occupation and career being considered. In other words, while science is concerned with "knowing, technology aims at "getting things done and done efficiently (Ogundele, 2013; Oranu, 2013; Seyi, 2014).

The provision of vocational guidance in our institutions has been necessitated by great changes in our society and the world at large, and has become more complex than ever before (Igberaharha \& Oroka, 2012). Automation and recession, for example, have forced many people into early retirement and retrenchment, resulting in unemployment. The rate of technological change, and the isolation of young people from possibilities for employment, has created problems in occupational choices (Aspen et al., 2015; Egbo \& Okifo, 2015). Many students are not able to obtain an informal exposure to a variety of occupations, nor can they easily obtain relevant data about them. Students have a limited knowledge of occupations and of the narrow range of alternatives available to them. This ignorance leads to unrealistic career aspirations. There is, therefore, a need to assist students to have more realistic career expectations. This study examined the extent at which vocational guidance influence the career decision taking of vocational and technical education students. Specifically, the study determined the extent to which vocational guidance has been able to influence career choice of vocational and technical education students; besides, this study also investigated the extent to which vocational guidance has been able to influence career choice of junior and senior vocational and technical education students. 


\section{METHODS}

This is a descriptive research design of the survey type. 220 technical students were sampled all technical education students in Ilorin metropolis. The research instrument was divided into sections A and B. Section A covers demographic information of the respondents while section B generate items on the extent at which vocational guidance influence career decision. Seven different questions were raised. The response mode was: To high extent, To some extent, To low extent and Not at all. To ascertain the validity of the instrument of this research, a draft copy of the questionnaire was validated by experts in the field of technology education. Their responses, comments and scrutiny were used to produce the final draft. A letter of introduction was taking to the head of the schools sampled to get approval to conduct the study in their institutions. The data collected were subjected to descriptive and inferential statistics. Frequency count and mean were used answer the research questions and Hypothesis was tested with t-test at 0.05 level of significance.

\section{RESULTS AND DISCUSSION}

\section{Results}

\section{Influence of Vocational Guidance on Influence Career Decision}

The extent at which vocational guidance has been able to influence career decision making of vocational and technical education students was investigated and the result presented in Table 1.

Table 1. Influence of Vocational Guidance on Influence Career Decision

\begin{tabular}{|c|c|c|c|c|}
\hline Items & $\begin{array}{c}\text { To High } \\
\text { Extent }\end{array}$ & $\begin{array}{c}\text { To Some } \\
\text { Extent }\end{array}$ & $\begin{array}{l}\text { To Low } \\
\text { Extent }\end{array}$ & $\begin{array}{c}\text { Not at } \\
\text { All }\end{array}$ \\
\hline $\begin{array}{l}\text { Vocational guidance creates occupational } \\
\text { information that is relevant to the career } \\
\text { choice of students. }\end{array}$ & $70(64.2 \%)$ & $39(35.8 \%)$ & - & - \\
\hline $\begin{array}{l}\text { Exposure to Vocational guidance has } \\
\text { made students understand } \\
\text { requirements of each occupation }\end{array}$ & $88(80.7 \%)$ & $21(19.3 \%)$ & 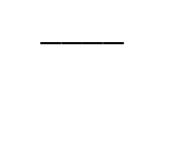 & . \\
\hline $\begin{array}{l}\text { Vocational guidance equips students with } \\
\text { necessary skills on collection of job } \\
\text { information. }\end{array}$ & $58(53.2 \%)$ & $42(38.5 \%)$ & $8(7.3 \%)$ & $\begin{array}{c}1 \\
(0.9 \%)\end{array}$ \\
\hline $\begin{array}{l}\text { Vocation guidance helps the students to } \\
\text { realize they can explore other } \\
\text { occupational fields apart from popularly } \\
\text { known ones. }\end{array}$ & $88(80.7 \%)$ & $18(16.5 \%)$ & $3(2.8 \%)$ & \\
\hline $\begin{array}{l}\text { With the help of vocational guidance } \\
\text { students can relate education to } \\
\text { employment opportunities. }\end{array}$ & $71(65.1 \%)$ & $37(33.9 \%)$ & $1(0.9 \%)$ & \\
\hline $\begin{array}{l}\text { Vocational guidance would go a long way } \\
\text { in giving the students the confidence to } \\
\text { decide what they want to do in future } \\
\text { without fear or doubt. }\end{array}$ & $68(62.4 \%)$ & $38(34.9 \%)$ & $3(2.8 \%)$ & \\
\hline $\begin{array}{l}\text { Vocational guidance helps students make } \\
\text { career choices that are in line with their } \\
\text { interests, aptitude and abilities }\end{array}$ & $88(80.7 \%)$ & $21(19.3 \%)$ & $\ldots$ & - \\
\hline
\end{tabular}


Table 1 revealed that exposure to vocational guidance has made students understand the requirements of each occupation and helps students make career choices that are in line with their interests, aptitude and abilities. Others followed suit as shown in Table 1. The findings established that vocational guidance has been able to influence career decision making of vocational and technical education students to a high extent.

\section{Significant Difference in the Impact of Vocational Guidance on Career Choice}

In other to ascertain the significant difference in the impact of vocational guidance on career choice, independent t-test was employed. Difference exist on the extent to which vocational guidance has been able to influence career choice of junior and senior vocational and technical education students presented in Table 2.

Table 2. T-test on Significant Difference in the Impact of Vocational Guidance on Career Choice

\begin{tabular}{lccccccc}
\hline Students & $\mathbf{N}$ & Mean & $\begin{array}{c}\text { Std. } \\
\text { Deviation }\end{array}$ & $\begin{array}{c}\text { Mean } \\
\text { Gain }\end{array}$ & df & t & Sig.(2-tailed) \\
\hline $\begin{array}{l}\text { Junior } \\
\text { Students }\end{array}$ & $\mathbf{8 0}$ & 2.98 & 0.163 & & & & \\
$\begin{array}{l}\text { Senior } \\
\begin{array}{l}\text { Students } \\
\text { Total }\end{array}\end{array}$ & 28 & $\mathbf{2 . 9 2}$ & 0.175 & & & & \\
\hline
\end{tabular}

Results in table 2 shows that the calculated t-value was 1.62 with significant value of 0.11 was not significant at 0.05 alpha levels because $p$-value was greater than 0.05 . This implies that the null hypothesis one was not rejected: hence, there was no significant difference in the impact of vocational guidance on career choice of junior and senior vocational and technical education students.

\section{Discussions}

Vocational education usually provided at upper secondary level, includes general education, practical training for development of skills required by the chosen occupations and related theory (Sahin, 2010; Verawadina et al., 2020). The proportions of these components may vary considerably but the emphasis is usually on practical training (Umeano, 2012; Wordu et al., 2013). This definition tends to pose problems of classification based on the level of entry of work, proportion of theoretical and scientific studies and emphasis on practical training. To avoid such debate in classification and to improve the development in this type of education, the current trends in education and planning and practices is to use a single term "technology education to embrace all such education programs. Technology deals with the application of knowledge in the solution of practical problems of everyday living. Technology education, essentially aims at developing techniques, devices, procedures and the process for doing things (Ferguson \& Hull, 2019). Obviously, theoretical and scientific studies and related skill training are required. These components will vary according to the level of education and the nature of occupation and career being considered. In other words, while science is concerned with "knowing, technology aims at "getting things done and done efficiently (Ogundele, 2013; Oranu, 2013; Seyi, 2014).

The provision of vocational guidance in our institutions has been necessitated by great changes in our society and the world at large, and has become more complex than ever before (Igberaharha \& Oroka, 2012). Automation and recession, for example, have forced many people into early retirement and retrenchment, resulting in unemployment. The rate of 
technological change, and the isolation of young people from possibilities for employment, has created problems in occupational choices (Aspen et al., 2015; Egbo \& Okifo, 2015). Many students are not able to obtain an informal exposure to a variety of occupations, nor can they easily obtain relevant data about them. Students have a limited knowledge of occupations and of the narrow range of alternatives available to them. This ignorance leads to unrealistic career aspirations. There is, therefore, a need to assist students to have more realistic career expectations

The findings of this study revealed that Vocational guidance has influence career choice of Vocational and Technology education students in Ilorin Metropolis. This is in line with the discussion who also found out that Vocational guidance has impact on career choice of secondary school students in Ilorin west (Anwana, 1989). Ani suggested that counselling intervention is adequately needed in Secondary schools in Ilorin West to address career decision making needs. He also added that instead of assuming that career maturity may naturally increase with age or higher grades, counsellors may develop and plan for systematic intervention which may be integrated component of the curriculum to provide the students with abundant opportunities and learning experiences to develop more mature career decision making attitudes and competencies.

The findings of this study also revealed that through exposure to Vocational guidance, students can understand the requirements of each occupation and this helps them to make career choices that are in line with their interest, aptitude, and abilities. This is supported by the findings of a sample of 130 bachelor students (Crişan et al., 2014). It was found out that the students are poorly informed regarding employment opportunities and that their expectations for the future are not connected with their own knowledge and skills, having no coherent outlined career plan, and thus facing major obstacles in the process if career decision making. This fact indicates that the students present a low degree of awareness of the advantages they can benefit from after the involvement in Career counselling programs. The finding established that Vocational Guidance has been able to influence career decision making of Vocational and technical students to high extent. This implies that students that are exposed to vocational guidance are likely to excel better in their career choice than others that are not exposed to Vocational Guidance.

\section{CONCLUSION}

This study concluded that vocational guidance influences career choice of Vocational and technology education students positively. The following recommendations were made based on the research findings: (1) Vocational and Technology Education students should be exposed to the importance of guidance services and what counseling is all about in order for them to make good career decisions; (2) Vocational and Technical Education Students should be enlightened through vocational guidance on the available and the right career path to take. This in essence would help reduce the level of unemployment among school leavers.

\section{REFERENCES}

Anwana, U. I. (1989). An analysis of occupational preferences of farm five students in secondary schools in. Cross River State Education, 3(1), 32-38.

Aspen, T., Cooper, R., Liu, Y., Marowa, M., Rubio, C., Waterhouse, E. J., \& Sheridan, J. (2015). What secondary schools advisors in New Zealand know about pharmacy and how that knowledge affects students career choice. American Journal of Pharmaceutical Education, 79(1). https://doi.org/10.5688/ajpe79107.

Ayçiçek, B. (2020). Investigation of the Students' Opinions on Vocational Guidance Services 
Conducted at High Schools. International Online Journal of Education and Teaching, 7(3), 827-842. https://eric.ed.gov/?id=EJ1258463.

Bedi, P., Goyal, S. B., \& Kumar, J. (2021). Applied Classification Algorithms Used in Data Mining During the Vocational Guidance Process in Machine Learning. Inventive Systems and Control, 137-146. https://doi.org/10.1007/978-981-16-1395-1_11.

Crișan, C., Pavelea, A., \& Ghimbuluț, O. (2014). A Need Assessment on Students' Career Guidance. Procedia - Social and Behavioral Sciences, 180, 1022 - 1029. https://doi.org/10.1016/j.sbspro.2015.02.196.

Egbo, J. O., \& Okifo, J. (2015). Guidance and counselling: a creativity for promoting sustainable well-being and adjustment of secondary school students in Nigeria. British Journal of Education, 3(10), 49-57.

El Haji, E., Azmani, A., \& El Harzli, M. (2018). Using the FAHP Method in the Educational and Vocational Guidance. International Journal of Modern Education \& Computer Science, 10(12).

Ezeji, S. C. (2014). Guidance and Counselling in Education. Chulbson International Press.

Ferguson, S. L., \& Hull, D. M. (2019). Exploring science career interest: Latent profile analysis of high school occupational preferences for science. Journal of Career Development, 46(5), 583-598. https://doi.org/10.1177\%2F0894845318783873.

Gargalianos, S., Makridis, G., Tsiaka, D., \& Kalaitzidou, D. (2021). Student Views on Vocational Guidance: Findings on Chronic Deficits-Suggestions to Meet Students Needs. RAIS Journal for Social Sciences, 5(1), 73-78. http://journal.rais.education/index.php/raiss/article/view/144.

Haug, E. H., Plant, P., Valdimarsdóttir, S., Bergmo-Prvulovic, I., Vuorinen, R., Lovén, A., \& Vilhjálmsdóttir, G. (2019). Nordic research on educational and vocational guidance: a systematic literature review of thematic features between 2003 and 2016. International Journal for Educational and Vocational Guidance, 19(2), 185-202. https://doi.org/10.1007/s10775-018-9375-4.

Igberaharha, O. C., \& Oroka, O. V. (2012). Fundamentals of Vocational Technical Education in Nigeria. Masega Publisher.

Jiang, Y. (2018). Explorations of Improvements in Vocational Guidance Course for College Students Driven by Innovation and Entrepreneurship Education. 2018 4th International Conference on Economics, Social Science, Arts, Education and Management Engineering (ESSAEME 2018), 280-286.

Ogundele, A. G. (2013). The place of technical Education towards skill acquisition to National development. IOSR Journal of Research and Method in Education (IOSRJRME), 3(5), 73-76. https://www.academia.edu/download/70125127/The_Place_of_Tech_edu.pdf .

Oranu, R. N. (2013). Problem of Vocational and Technical Education in Nigeria. Conference on Vocational and Technical Education.

Sahin, M. (2010). Blended learning in vocational education: An experimental study. International Journal of Vocational and Technical Education, 2(6), 95-101. https://doi.org/10.5897/IJVTE.9000007.

Seyi, D. (2014). An overview of Vocational and technical education in Nigeria under secondary school system. International Journal of Technology Enhancements and Emerging Engineering Research, 2(6), 119-122. http://citeseerx.ist.psu.edu/viewdoc/download?doi=10.1.1.443.8876\&rep=rep1\&type= pdf.

Turganbayev, Y., Adilgazinov, G., Barabanova, Y., Zhakupov, A., \& Zhukibayeva, G. (2021). Information System for Vocational Guidance, Employment and the Forecasting of Labor Demand: The Case of Kazakhstan. 2021 IEEE International 
Conference on Smart Information Systems and Technologies (SIST), 1-6.

Umeano, E. C. (2012). Perceived Parent-Youth Relationship and its Socio- Psychological Implications for Students: The Case of University of Nigeria, Nsukka. Nigerian Journal of Empirical Studies in Psychology and Education, 1(5), 22-29.

Verawadina, U., Jalinus, N., \& Widya, R. (2020). Needs Assessment of E-Learning Vocational Education. 11(4), 262-274.

Wordu, C. C., Igweagbara, S. N., Borden, S. U., \& Akue, N. P. (2013). The Relevance of Vocational Guidance in Vocational Technical Education Training Programme in Nigeria. Journal of Technology and Vocational Educators, 3(1), 62-67.

Young, L. U. (2017). The role of guidance counsellors in the career in the career development of adolescent and young adult with special needs. British Journal of Arts and Social Sciences, 2(1), 51-62. 